\title{
REFERENCES
}

Bartlett, S., Henry, K. M., Kon, S. K., Osborne, L. W., Thompson, S. Y. \& Tinsley, J. (1938). Biochem. F. 32, 2024.

Bell, J. M. \& Loosli, J. K. (195 r). F. Anim. Sci. xo, 50.

Bender, A. E. (1956). Brit. F. Nutr. 10, 135.

Block, R. J. \& Mitchell, H. H. (1946-7). Nutr. Abstr. Rev. r6, 249.

Columbus, A. (1954). Arch. Tierernähr. Beihefte, no. 4, p. 5 I.

Henry, K. M. \& Kon, S. K. (1956). Brit. F. Nutr. 1o, 39.

Henry, K. M. \& Kon, S. K. (1957). Brit. F. Nutr. I1, 305.

Ma, T. S. \& Zuazaga, G. (1 942). Industr. Engng Chem. (Anal.), 14, 280.

Macrae, T. F., Henry, K. M. \& Kon, S. K. (1943). Biochem. F. 37, 225.

Mayfield, H. L. \& Hedrick, M. T. (1949). F. Nutr. 37, 475.

Miller, D. S. \& Bender, A. E. (1955). Brit. F. Nutr. 9, $3^{82 .}$

Mitchell, H. H. (1923-4a). F. biol. Chem. 58, 873 .

Mitchell, H. H. (1923-4b). F. biol. Chem. 58, 905.

Mitchell, H. H., Burroughs, W. \& Beadles, J. R. (1936). F. Nutr. Ir, 257.

Mitchell, H. H. \& Carman, G. G. (1926). F. biol. Chem. 68, i83.

Nehring, K. \& Haesler, E. (1954). Arch. Tierernähr. Beihefte, no. 5, p. I 10.

Njaa, L. R. (1959). Brit. F. Nutr. 13, 142.

Snedecor, G. W. (1946). Statistical Methods Applied to Experiments in Agriculture and Biology, 4th ed. Ames, Iowa: The Iowa State College Press.

Sure, B. (1941). F. Nutr. 22, 499.

\section{Biological value of herring-meal protein. Urinary nitrogen excretion in relation to protein content of diet and food intake}

\author{
By L. R. NJAA \\ Governmental Vitamin Laboratory, Norwegian Fisheries Research Institute, \\ Bergen, Norway \\ (Received $\mathrm{I}_{4}$ Fuly $\mathrm{1} 95^{8}-$ Revised $\mathrm{I} 2$ Fanuary 1959)
}

In a previous communication ( $\mathrm{Njaa}$, I959) a close relationship between the growth rate of experimental rats and the biological value of herring-meal protein determined on them was demonstrated. Analysis of covariance indicated that under the conditions used the body-weight was of minor importance. The food intake and the protein concentration of the diets were kept constant. Increased protein content of the diet has been reported to decrease the biological value, but variations in the intake of food of a constant protein content were without effect (Mitchell, 1923-4). Though the former observation has been confirmed by many (Chick, Boas-Fixsen, Hutchinson \& Jackson, I935; Columbus, I954; Nehring \& Haesler, 1954; Henry \& Kon, 1957; Forbes, Vaughan \& Yohe, I958), confirmation of the latter does not seem to have been published. The observations of Bender (1956) that net protein utilization for rollerdried skim milk and for bread fortified with lysine did not vary with the food intake have no direct bearing on this point since the different food intakes were not compared in the same experiment. 
The object of my investigation was to study the influence of the nitrogen intake upon the biological value of a herring-meal protein. The intake was varied by varying either the food intake at a constant protein content, or the protein content at a constant food intake. It. was soon realized that the urinary excretion of nitrogen was the important variable to be studied. Therefore, in two experiments, determinations of metabolic and endogenous nitrogen losses were omitted. The effect of protein content upon the biological value observed by Mitchell (1923-4) was confirmed. The results indicated, however, that the numerical difference between biological values was greatly influenced by the assumptions made about the magnitude of endogenous urinary nitrogen excretion.

When the food intake was varied and the experimental animals were of similar body-weight an increased food intake seemed to increase the biological utilization of dietary nitrogen.

\section{EXPERIMENTAL}

The biological values were determined either by the original Mitchell method or by a shortened version of it as described by Njaa (1959). When only urinary nitrogen excretion was considered, six triads of litter-mate rats were used in each experiment. Within litters the rats were of the same sex and one rat from each triad was allotted to each treatment. If a rat failed to consume its daily ration completely, or if samples of faeces or urine were lost, the results for it and its litter-mates were omitted from the calculations. The herring meal (no. 3) which was used in all experiments contained $73.3 \%$ conventional protein $(\mathrm{N} \times 6.25)$. The experimental diets contained 6,8 or $10 \%$ protein. The protein content of the diet was varied by changing on an equalweight basis the proportions of the protein source and of the partly dextrinized potato starch.

\section{Expt I. Effect of food intake upon the biological value of a herring-meal protein and upon the quantities determining this value}

Two herring meals were compared at the $10 \%$ level of protein intake in an experiment in which the original version of Mitchell's method ( $\mathrm{Njaa}$, 1959) was used. Only results for one of them, no. 3 , are considered here. All rats received $8 \mathrm{~g}$ food daily in the first low egg-protein period and in the second feeding period with the two herringmeal diets. In the third and fourth periods all rats received rog daily. They were 4-5 weeks old at the beginning of the experiment, which lasted for 40 days.

\section{Expt 2. Effect of protein content of the diet upon the biological value of a herring-meal protein and upon the quantities determining this value}

Herring meal no. 3 was tested by the shortened version of the Mitchell method (Njaa, 1959) at the 6,8 and 10\% levels of protein intake in two experimental periods 2 weeks apart. Six groups of four litter-mate rats of the same sex within groups were used. Each rat received the same diet throughout the experiment, including the gap between experimental periods, at the uniform rate of $10 \mathrm{~g} / \mathrm{rat} / \mathrm{day}$. The rats were 4-5 weeks old at the beginning of the experiment. The gap between the periods in 
this experiment and in Expt 3 made it possible to compare the effects of treatments after a short (4 days) and after a rather long (24 or $3^{1}$ days) period of preliminary feeding.

\section{Expt 3. Effect of food intake upon urinary excretion of nitrogen, expressed as a percentage of the nitrogen intake}

Herring meal no. 3 was given in two experimental periods at a level to supply $10 \%$ of protein in the diet. The daily food intakes were $8.33,10.0$ and $12.0 \mathrm{~g} / \mathrm{rat}$ in the three groups tested. Older rats (about ro weeks) had to be chosen to have them eat the largest rations. The two periods were 3 weeks apart but the arrangement otherwise was as in Expt 2.

\section{Expt 4. Effect of food intake and protein content of the diet upon urinary excretion of nitrogen, expressed as a percentage of the nitrogen intake}

Herring meal no. 3 was tested in one experimental period at levels to supply 8 and $10 \%$ protein, the food intake being 8 or $10 \mathrm{~g} / \mathrm{rat} / \mathrm{day}$. The group receiving $10 \mathrm{~g}$ daily of the $10 \%$ protein diet was chosen as a reference, and the groups receiving respectively $8 \mathrm{~g}$ daily of the $10 \%$ protein diet and $\mathrm{Io} \mathrm{g}$ daily of the $8 \%$ protein diet were compared with this reference group and with each other. The rats were 4-5 weeks old at the beginning of the experiment.

RESULTS

The results of Expts $\mathrm{I}-4$ are given in Tables $\mathrm{I}-4$.

Expt $\mathrm{x}$. The biological value and the net protein utilization were higher and the term $100 U / I(U$, urinary nitrogen; $I$, nitrogen intake) correspondingly lower at the lower food intake. The differences were significant (Table $\mathrm{I}$ ). True digestibility and the term $100 U^{\prime} / I\left(U^{\prime}\right.$, endogenous urinary nitrogen) were scarcely influenced by the change in food intake. The growth rate was better at the higher food intake.

Expt 2. The biological value, the net protein utilization, the true digestibility and the term $100 U^{\prime} / I$ were higher the lower the protein concentration. The mean bodyweight and the mean growth rate varied in the opposite direction. The term rooU/I was practically unaffected by the protein content of the diet. Analysis of variance indicated significant differences between protein levels except for the term $100 U / I$; mean body-weight and $10 \circ U^{\prime} \mid I$ were not tested. Biological value and net protein utilization were significantly higher in period 2 than in period I. The numerical differences observed were mainly due to corresponding differences between the values for the term $100 U / I$ and for the term $100 U^{\prime} \mid I$. Within treatments, values of the latter term are determined by the magnitude of the endogenous urinary excretion of nitrogen $\left(U^{\prime}\right)$, which in turn is determined by the assumptions made about this excretion. The rather low values for the term $100 U / I$ in period 2 were associated with relatively high growth rates in rather heavy rats. The interaction between periods and treatments was not significant. This indicated that the length of the preliminary feeding period did not influence the effects of treatments.

Expt 3. The term rooU/I decreased, the mean body-weight and the mean growth 


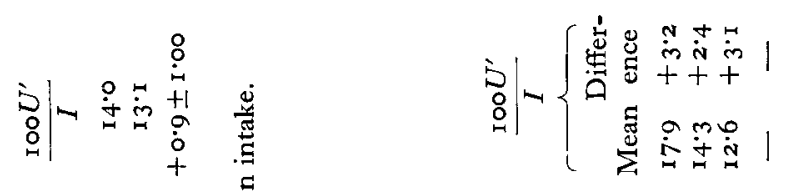

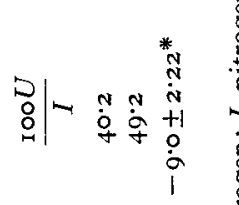

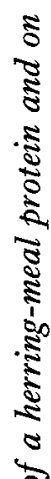

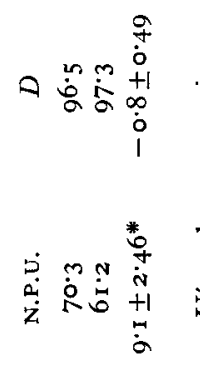

焉

(ั) 尊

(2)

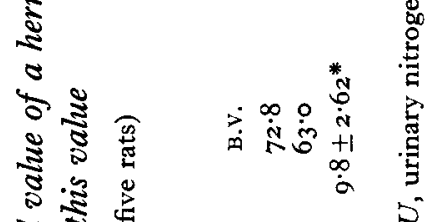

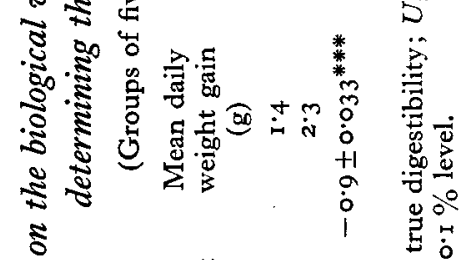

5

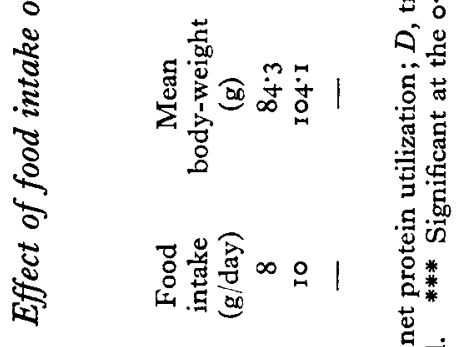

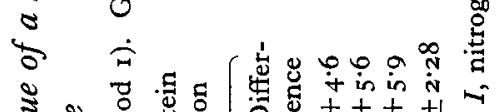

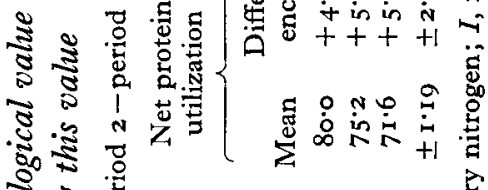

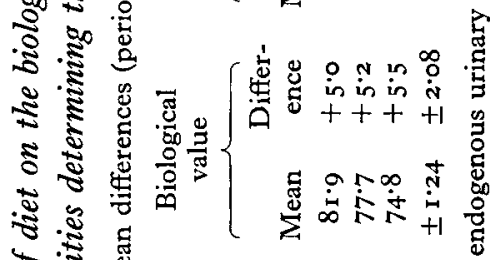
穴.

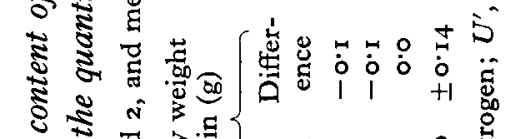

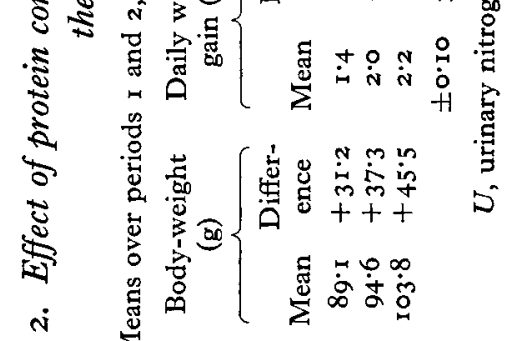


rate increased, with increased food intake. For roo $U / I$ and the mean growth rate, analysis of variance indicated significant differences between food-intake levels and between periods. The interaction between periods and treatments was not significant for the term $100 U / I$. This finding indicated that the length of the preliminary feeding period did not influence the effects of treatments on the term.

Table 3. Expt 3. Effect of food intake on excretion of urinary nitrogen and on body-weight

(Means over two periods and mean differences (period 2-period 1 ). Groups of five rats)

\begin{tabular}{|c|c|c|c|c|c|c|c|}
\hline \multirow{2}{*}{$\begin{array}{c}\text { Protein } \\
\text { content } \\
\text { of diet } \\
(\%)\end{array}$} & \multirow{2}{*}{$\begin{array}{c}\text { Food } \\
\text { intake } \\
\text { (g/day) }\end{array}$} & \multicolumn{2}{|c|}{ Body-weight (g) } & \multicolumn{2}{|c|}{$\begin{array}{c}\text { Daily weight } \\
\text { gain (g) }\end{array}$} & \multicolumn{2}{|c|}{$\frac{100 U}{I}$} \\
\hline & & Mean & Difference & Mean & Difference & Mean & Difference \\
\hline Io & $8 \cdot 33$ & II $7 \cdot 0$ & $+I_{5} \cdot 1$ & 0.8 & +0.4 & $69 \cdot 2$ & $+8 \cdot I$ \\
\hline 10 & 10.0 & $130 \cdot 6$ & +24.8 & $\mathrm{I} \cdot 4$ & -0.3 & $58 \cdot 7$ & $+5 \cdot 2$ \\
\hline I0 & $12 \cdot 0$ & $147 \cdot 0$ & $+37 \cdot 9$ & $2 \cdot 1$ & $-1 \cdot 2$ & $52 \cdot 8$ & $+7 \cdot 3$ \\
\hline \multicolumn{3}{|c|}{ Standard error ( 8 d.f.) } & & $\pm 0.1 I$ & \pm 0.27 & $\pm 2 \cdot 29$ & $\pm 1 \cdot 82$ \\
\hline
\end{tabular}

Table 4. Expt 4. Effect of food intake and protein content of diet on the excretion of urinary nitrogen, expressed as a percentage of the nitrogen intake

(Groups of five rats)

\begin{tabular}{|c|c|c|c|c|}
\hline $\begin{array}{c}\text { Protein } \\
\text { content } \\
\text { of diet }(\%)\end{array}$ & $\begin{array}{c}\text { Food } \\
\text { intake } \\
(\mathrm{g} / \text { day })\end{array}$ & $\begin{array}{c}\text { Mean } \\
\text { body-weight } \\
\text { (g) }\end{array}$ & $\begin{array}{c}\text { Mean } \\
\text { daily weight } \\
\text { gain }(\mathrm{g})\end{array}$ & $\frac{100 U}{I}$ \\
\hline 8 & Io & $87 \cdot I$ & $\mathrm{I} \cdot 8$ & $4 I \cdot 3$ \\
\hline IO & IO & $9 r \cdot 7$ & $2 \cdot 2$ & $45^{\circ} \circ$ \\
\hline IO & 8 & $83 \cdot 6$ & $1 \cdot 2$ & $5 I \cdot 4$ \\
\hline \multicolumn{3}{|c|}{ Standard error ( 8 d.f.) } & \pm 0.09 & $\pm \mathrm{I} \cdot 6 \mathrm{I}$ \\
\hline
\end{tabular}

$U$, urinary nitrogen; $I$, nitrogen intake.

Expt 4. With the group receiving $10 \mathrm{~g} / \mathrm{rat} /$ day of the $10 \%$ protein diet as reference, lowering of the protein concentration resulted in a lowered value for $100 U / I$, and lowering of the food intake resulted in an increased value for rooU/I. Analysis of variance indicated significant differences between treatments. The effect upon rooU/I of changing food intake was greater than that of changing the protein content of the diet. It also was so when the growth rate was considered. Differences between the mean body-weights were not tested.

\section{DISCUSSION}

It is convenient for the following discussion to break down the biological value, B.v., into the terms of equations $I$ and 2

$$
\begin{gathered}
\frac{\text { B.V. } \times D}{100}=\text { N.P.U. } \%, \\
\text { N.P.U. }=D-100 U / I+100 U^{\prime} \mid I,
\end{gathered}
$$

in which $D$ is the true digestibility, N.P.U. the net protein utilization, $I$ the nitrogen intake, $U$ the urinary nitrogen and $U^{\prime}$ the endogenous urinary nitrogen. 
$D$ varied only slightly when the food intake and the protein content of the diet were varied. Also, between experiments $D$ was fairly constant (Expts I and 2). $D$ was therefore considered to be constant for one and the same protein source, in agreement with the findings of Allison, Anderson \& Seeley (1946), and of Forbes et al. (1958). The validity of this assumption will be discussed in a later communication. On this assumption, conclusions arrived at for N.P.U. will be valid for B.V. (equation I). Variations in N.P.U. are brought about by variations in the terms $100 U / I$ and $100 U^{\prime} / I$ (equation 2). Only the former of these terms may be studied experimentally in relation to the nitrogen intake (Mitchell, 1955).

Table 5. Mean values for the term $100 U / I$, age and growth rate of rats given daily $10 \mathrm{~g}$ of the diet containing herring meal at the $10 \%$ protein level in Expts $\mathrm{I}-4$, arranged according to increasing $100 U / I$ values

\begin{tabular}{|c|c|c|c|c|c|}
\hline$\frac{100 U}{I}$ & $\begin{array}{l}\text { Age of rats } \\
\text { (days) }\end{array}$ & $\begin{array}{l}\text { Mean body- } \\
\text { weight (g) }\end{array}$ & $\begin{array}{c}\text { Mean daily } \\
\text { weight gain (g) }\end{array}$ & Expt no. & $\begin{array}{l}\text { Period } \\
\text { no. }\end{array}$ \\
\hline $35 \cdot 7$ & $5^{6}$ & $126 \cdot 6$ & $2 \cdot 2$ & 2 & 2 \\
\hline $37 \cdot 6$ & 33 & $8 I \cdot I$ & $2 \cdot 2$ & 2 & $\mathbf{I}$ \\
\hline $45^{\circ} 0$ & 38 & $91 \cdot 7$ & $2 \cdot 2$ & 4 & - \\
\hline $49 \cdot 2$ & 55 & 104.7 & $2 \cdot 3$ & I & 2 \\
\hline $56 \cdot I$ & 73 & I I $8 \cdot 2$ & $1 \cdot 5$ & 3 & I \\
\hline $6 x \cdot 3$ & 95 & $143^{\circ} \mathrm{O}$ & $1 \cdot 2$ & 3 & 2 \\
\hline
\end{tabular}

$U$, urinary nitrogen; $I$, nitrogen intake.

Inferences about N.P.U. may be sought by discussing the relationship between $100 U / I$ and the nitrogen intake. The biological value of protein has been reported to vary with the body-weight, with the age of the experimental animals, or with both (Bell \& Loosli, 195 I ; Henry \& Kon, 1957) and also with the growth rate (Njaa, 1959). These authors found the lowest values with the heaviest or the oldest or the slowestgrowing animals. In Table 5 are summarized the $100 U / I$ values obtained in Expts I-4 when the daily food intake was $\mathrm{I}$ g/rat and the protein content of the diet was Io $\%$. Values for age, body-weight and growth rate are also given. The term $100 U / I$ seemed to vary rather closely with the age and the body-weight, except in the second period of Expt 2 in which an exceptional low value for rooU/I was observed. It was, however, associated with a relatively high growth rate in rather heavy rats. The values in Table 5 are therefore in general agreement with the literature findings cited. Within experiments the rats were of similar age, but it was not possible with the experimental procedures used to compare rats of equal body-weight. In Expts 2-4 the initial weights were similar, but even the preliminary feeding period of 4 days introduced body-weight differences. It is believed, however, that at least in the first periods of Expts 2 and 3 and in Expt 4 the rats were of similar body-weight within experiments.

It is important to consider whether the protein utilization was differently affected when the protein intake was changed either by changing the food intake at a constant protein level or by changing the protein level at a constant food intake.

When protein utilization is compared on the basis of the $100 U / I$ values, a higher food intake was associated with a lower protein utilization in Expt I and with a higher 
utilization in Expts 2 and 4. A higher protein level seemed to be associated with a lower but nearly constant protein utilization in Expt 2, and with a lower utilization in Expt 4. Changes in the food intake influenced the variation in $100 U / I$ more than did changes in the protein concentration.

The results obtained in Expt I were of doubtful value as not only the food intake but also the age and the body-weight had changed from period 2 to period 3 . The change observed in the $100 U / I$ value may have been related to age or to body-weight or to both (Table 5 ).

The results obtained in Expts 2-4 agreed in indicating that the protein utilization was differently affected by the two ways of changing the protein intake. This difference was most clearly seen in Expt 4 in which the two ways were simultaneously tested. An explanation of this different effect of the intake changes on the $100 U / I$ values may be sought in the observed growth rates. The growth rate increased when protein intake increased in Expts 2 and 3. In the former the increase in the growth rate was less rapid, in the latter more rapid, than the increase in the protein intake. In Expt 4 the change in the food intake influenced the growth rate more than did the change in the protein level. Within periods, the growth rate therefore seemed to give the same indications about the protein utilization as did the $100 U / I$ values. Between periods it did not seem to be so (Expt I, Table I).

Other main points worthy of consideration are whether the N.P.U. value (or B.v.) was lower at higher protein levels than it was at lower levels, and whether the N.P.U. value (or B.v.) was unaffected by variations in the food intake. These questions cannot be answered unless the magnitude of the endogenous urinary excretion of nitrogen $\left(U^{\prime}\right)$ is known. With equation (2) and the observed values for $I$ and $100 U / I$, the values for $U^{\prime}$ consistent with constant N.P.U. at different nitrogen intakes were calculated from the values in Expts 2-4. Those for different protein levels gave by calculation slightly negative (Expt 2) or decidedly negative (Expt 4 ) values for $U^{\prime}$. If a constant endogenous urinary excretion of nitrogen is assumed (Folin, 1905; Mitchell, 1955), these results indicate that N.P.U. (and B.v.) was lower at the higher protein levels. Calculation from the values for different food intakes gave for $U^{\prime}$ about $60 \mathrm{mg}$ nitrogen/rat/day in Expt 3 and about 40 in Expt 4. If these values are distinctly higher than normal endogenous urinary nitrogen excretion, a higher N.P.U. (and B.v.) at the higher food intakes would be indicated. Mitchell (1948) found $0.6 \mathrm{mg}$ nitrogen/g (body-weight) $)^{0.75}$ as the mean value of 156 estimations of the daily endogenous urinary excretion in the young rat. Calculations from the values with the low egg-protein diet in Expts I and 2 gave approximately the same mean value as that found by Mitchell (1948). With endogenous urinary excretion of this magnitude for the rats in Expts 3 and 4 , the daily excretions from this source would be in the range 1 5-30 $\mathrm{mg}$ nitrogen/rat/day. These values agree well with the tabulations of the endogenous urinary nitrogen for rats of different body-weight given by Columbus (1954) and by Nehring \& Haesler (1954). Thus, the values for $100 U / I$ obtained at a constant protein level and at different food intakes imply that protein was utilized better at the higher food intakes. This inference does not agree with Mitchell's (1923-4) conclusions on this point. Mitchell's data were, however, obtained with rats of greatly differing body-weight 
and growth rate. It is conceivable that any effect of the food intake upon the biological value may have been masked by the effects of body-weight and growth rate. On the other hand, Bender (1956) demonstrated a positive correlation between the N.P.U. and the voluntary food intake for different proteins given at a constant dietary level. My findings indicate that it may have been a consequence of the variation in the food intake per se. In a recent publication Forbes et al. (1958) observed a tendency for the biological value of casein to be lower at a daily food intake of $6 \mathrm{~g}$ than with 8 or $\mathrm{ro} \mathrm{g}$.

Determinations of N.P.U. or B.v. aim at comparing different protein sources on the basis of their available amino-acid set-up. My results, and those of Bender (1956) and of Forbes et al. (1958), indicate that such comparisons should be made at a constant food intake.

Calculation of $U^{\prime}$ by means of equation (2) is equivalent to the linear extrapolation to the hypothetical urinary nitrogen excretion at zero nitrogen intake. Extrapolation procedures have been used for estimation of endogenous urinary nitrogen by Mitchell (1955) with rats, and by Armstrong \& Mitchell (1955) with pigs. These workers, and quite recently Forbes et al. (1958) who worked with rats, estimated total metabolic nitrogen losses (faecal and urinary) by extrapolating the nitrogen balance against the absorbed nitrogen. The last workers observed significant curvilinearity of regression so that linear extrapolation at times underestimated the total metabolic nitrogen losses. This finding is in agreement with mine. In the experiments of Forbes et al. (1958) the food intake was kept within a narrow range, in Mitchell's (1955) experiments the food intake in all probability was not constant, and in Armstrong \& Mitchell's (1955) experiments food-intake variations were noted. In the last, body-weight changes were also obvious.

Changes in protein level and food intake may influence urinary nitrogen excretion in opposite directions when body-weight is constant. When this condition is not fulfilled, more complex relations may be assumed. Therefore, extrapolation procedures for estimation of endogenous urinary nitrogen may be considered to give reliable results only under strictly standardized conditions, and even then factors such as growth rate may not be under control (cf. Table 5).

In some instances, when the protein level was low, increase in it did not result in decreased B.v. (Henry \& Kon, 1957). It is conceivable that this situation may be explained by assuming that the effects of food-intake and concentration changes have balanced each other or that, in the lower concentration range, growth rate and concentration have increased at the same rate, or that both effects were involved.

From the results of Expt 2 (Table 2) the deciding importance of the term roo $U^{\prime} \mid I$ in determining the numerical value of differences in N.P.U. between protein levels and between experimental periods is evident. For a given range of variation in $I$, any variation in $100 U^{\prime} / I$ will be lower the lower the value ascribed to $U^{\prime}$.

The interpretation of my results and of those cited from the literature did not require questioning the constancy of endogenous urinary nitrogen. On the other hand, no clue as to the magnitude of this excretion was obtained. This problem, and the question whether consumption of protein depresses endogenous urinary nitrogen excretion will be discussed in a later communication. 


\section{SUMMARY}

I. Relationships between biological value of a herring-meal protein and the food intake or the dietary protein concentration were studied in experiments with young rats.

2. Inferences about the biological value were drawn from observed variations in the urinary nitrogen excretion, expressed as a percentage of the nitrogen intake. The latter was varied either by varying the food intake at a constant protein level or by varying the protein level at a constant food intake. The importance of comparing rats of the same age and of similar body-weight was demonstrated.

3. The utilization of protein was lowered when its level in the diet was increased, but was improved when the food intake was increased. These conclusions were based upon prevalent assumptions about endogenous urinary nitrogen. The part of the growth rate in determining the different responses to increased protein intake was indicated.

4. It is concluded that extrapolation procedures for estimation of endogenous urinary nitrogen should be used only under strictly standardized conditions.

5. The importance of endogenous urinary nitrogen in determining numerically differences in biological values is stressed.

\section{REFERENCES}

Allison, J. B., Anderson, J. A. \& Seeley, R. D. (1946). Ann. N. Y. Acad. Sci. 47, 245.

Armstrong, G. D. \& Mitchell, H. H. (1955). F. Anim. Sci. 14, 49.

Bell, J. M. \& Loosli, J. K. (195 I). F. Anim. Sci. 10, 50.

Bender, A. E. (1956). Brit. F. Nutr. Io, 135.

Chick, H., Boas-Fixsen, M. A., Hutchinson, J. C. D. \& Jackson, H. M. (I935). Biochem. F. $29,1712$.

Columbus, A. (1954). Arch. Tierernähr. Beihefte, no. 4, p. 5 I.

Folin, O. (1905). Amer. F. Physiol. 13, I17.

Forbes, R. M., Vaughan, L. \& Yohe, M. (I958). F. Nutr. 64, 291 .

Henry, K. M. \& Kon, S. K. (1957). Brit. F. Nutr. Ir, 305.

Mitchell, H. H. (1923-4). F. biol. Chem. 58, 905.

Mitchell, H. H. (1948). In Proteins and Amino Acids in Nutrition, Chapter 2, p. 58. [M. Sahyun, editor.] New York: Reinhold Publishing Corp.

Mitchell, H. H. (1955). Ұ. Nutr. 55, 193.

Nehring, K. \& Haesler, E. (1954). Arch. Tierernähr. Beihefte, no. 5, p. I Iо.

Njaa, L. R. (1959). Brit. F. Nutr. 13, 137. 